Global Conferences Series:

Social Sciences, Education and Humanities (GCSSSEH), Volume 3, 2019

The $1^{\text {st }}$ International Conference on Education, Social Sciences and Humanities

DOI: https://doi.org/10.326/hum0219

\title{
Implementing On-line Scientific Collaboration Editing to Increase Lecturer's Research Publication
}

\author{
Eka Pramono Adi', Henry Praherdhiono ${ }^{2}$, Yulias Prihatmoko ${ }^{3}$ \\ ${ }^{123}$ Universitas Negeri Malang, Malang Indonesia \\ eka.pramono.fip@um.ac.id
}

\begin{abstract}
Scientific publications have become a trend in the field of academics. As the development of trends in publications turns into a necessity. Lecturers are required to conduct scientific publications as a form of implementation of the Tridarma of Higher Education. Lecturers have a community that needs a vehicle to construct knowledge in the style of collaborative scientific writing. Management of scientific paper is essential, one form is collaboration. Collaboration has the opportunity to achieve significant improvements in the scientific publications of lecturers at Universitas Negeri Malang (UM). The online collaboration concept is felt to provide facilities that allow lecturers at UM to create, publish works that are rich in digital content in new or existing communities. The goal is to increase the scientific publications of lecturers with a collaborative system of writing scientific work among lecturers at UM based online.
\end{abstract}

Keywords: scientific publications, community lecturers, collaboration.

\section{Introduction}

It was stated in Law No. 14 of 2015 concerning Teachers and Lecturers in Article 60 that it was stated that in carrying out professional duties, lecturers were obliged to, among others, carry out education, research, and community service. Often referred also to Tridharma college high. Furthermore, based on Law Number 12 of 2012 concerning Higher Education in Article 12 paragraph (2) and (3) it is stated that lecturers as scientists have the task of developing science and/or technology through scientific reasoning and research as well as disseminating it. Lecturers are also required to conduct scientific publications as a source of learning.

Lecturer as a scholar was the publication of scientific already become a trend in developing the profession. Along with the terms of the issued also permenristekdikti No. 20 of 2017 concerning the obligations of lecturers in improving the publication of scientific. Citing a speech Menristek Higher Education on the date of 30 March 2017 in Bogor "Scientific research and publications are important elements in the world of education. Scientific research and publications are like two sides of a coin that can not be separated. Results of research scientists are not published only going to be a pile of documents which fills the corner space of the library.

Copyright ( 2019, the Authors. Published by Redwhite Press. 
" The results of research science in college high should be published, so that the research that has a meaning more and gives a contribution to the dissemination of scientific knowledge " so also were delivered by The Minister of Higher Education on the speech of them.

Based on the regulations and a statement that the publication is a must for lecturers to support professionalism . will but in the paper of scientific, not uncommon lecturer experiencing difficulties. Based on the results of Adi's (2014) research on scientific writing in collaboration the challenges that are often faced by the lecturer is difficult to divide time between the solid hours of teaching, less the collaboration between lecturer senior and lecturer young, and yet the system that can make media for collaboration in research.

Research applications content management system (CMS) in Universitas Negeri Malang (UM) has been initiated by a team of researchers Department of Technology Education since 2007. The development of institutions K-1 INHERENT has resulted in system applications Learning On-line (Saprol) were used until now. SAPROL was developed by combining CMS with the Learning Management System (LMS). With their, Saprol can facilitate and media community of faculty to construct a form of writing works of science is collaborative (Adi, 2018; Adi and Praherdhiono, n.d.; Husna et al., 2017). With management that is either not close the possibility for the realization of the increase publication scientific faculty.

Collaborative development of editing works on-line scientific work will provide comfort to lecturers in terms of ease of access and flexibility of learning resources. (Windana et al., 2015; Praherdhiono 2015) stated that the convenience of an ergonomically learning environment is supported by physical locations such as buildings in universities, libraries or classrooms, as well as learning devices both digital and non-digital devices. This statement was sharpened in the Partnership for 21st Century Skills (2009) that the learning tools that are included in online learning environtment is a learning device, virtual schools, and combine digital and non-digital devices.

Community lecturers require a vehicle for constructing knowledge in the form of writing a scientific basis collaboratively. According to (Tu, 2002a, 2002b; Tu and Corry, 2002) Communities are incorporated in online has been regarded as one of the concepts of the most important in the learning -based technology web. Malang State University does not yet have a collaboration community write scientific online specifically for faculty. The process of learning to write science that involves collaborative ability need to be proposed as factors fundamental to be a cornerstone of community learning to write scientific online among lecturers (Boscolo and Ascorti, 2004; Sutherland and Topping, 1999). The existence of the community is to ensure lecturers as participants in the online community at the State University of Malang and the academic community will grow and develop in terms of acquiring knowledge that is spread among lecturers.

\section{Method}

In the framework of the implementation of collaborative editing of works of science are online is activities divided into two cycles adapted to the allocation of time and the selected topic. Each cycle consists of four steps (Kemmis et al., 2015; McTaggart and Nixon, 2018) the following: a) planning, namely formulating the problem, determining the objectives and methods of research and making an action plan, b) actions, which are carried out as an effort to make changes, and c ) reflection, which is reviewing and considering the results or effects of the operations taken.

Operationally the action research procedures applied in this study are described as follows:

\section{Stage I: Preparation}

This stage consists of 
- Form a Task Force consisting of senior lecturers as reviewers, young lecturers as writers and laboratory staff as managers within the Department of Education Technology, Universitas Negeri Malang.

- Creating a climate and understanding about the management of the writing of the work of the scientific basis of collaboration between faculty Education Technology UM.

\section{Stage II: Implementation}

Phased implementation of the editing work of the scientific basis of online done at the level of local and internet. Applications need to be carried out tests use it carefully. The activities are intended to be in the implementation of the study do not occur interference in technical. Limited execution will be carried out at the Department server laboratory Educational Technology.

Model implementation includes four steps that must be taken are as follows :

1. The first step is to register the user on the application later me give right of access to each user in accordance with the right of access.

2. Step Two, designing governance and rule in the editing work of science in line between the reviewer by the author.

3. Step Three, do activities upload work writing scientific results of research and reviewer of the work of writing is the collaboration and to produce works of writing scientific basis finals.

4. Step Four did submit to journals nationally or internationally and proceedings of national and international.

\section{Stage III: Reflection of activities}

In the fourth stage carried reflection on the implementation of the editing work of scholarly online in a collaborative, with a view to obtaining a picture of how far the level of the attractiveness, suitability application, ease of access to messages, and the effectiveness of the strategy of presenting the material.

Implementation of limited editing online is carried out on a lecturer Department of Technology Education FIP UM. The number of lecturers TEP UM number of 18 people was divided into two lecturers to the post of Professor, 4 People Associate Professor Head, 6 people Lectureship, and 6 the Assistant Expert. As for the overall implementation involving 3 institutions, namely the Education Technology Department of FIP UM, Pusdikbang SDM Perhutani located in Madiun and STT dharma Iswara Madiun.

\section{Results And Discussion}

\section{Web implementation in institutions}

The implementation of joint writing is carried out on 3 institutions that have different characteristics. The first institution for implementation was Educational Technology, State University of Malang. The characteristics of Educational Technology institutions in Malang State University are those with the character of education with the content of developing learning technology. The lecturer in educational technology has awareness about the importance of writing as scientific development. 
The productivity of writing can be said to be in a good category, which means that each lecturer has one published paper.

The second and third institutions are partner institutions that have been willing to join together to develop the web jointly. The partner institutions are Pusdikbang SDM Perhutani located in Madiun and STT dharma Iswara Madiun. Perhutani HR Pusdigbang Partners have the characteristics of training institutions that produce graduates who have competence in the field of forestry and empowerment of the environment around the forest community. Writing in institutions is training modules, technical KIT about forest conservation, etc. Writing works are only used in the developer environment and are not well publicized. Therefore conditions like this are ideal conditions to become partners. The next partner institution is STT Dharma Iswara Madiun. The main characteristic of this institution is Design and Animation Technology as a scientific content with HR, especially lecturers who are still very young and have enormous potential in writing. In general, it can be described that this partner institution is still in the category of not having sufficient capacity in writing scientific papers, so it is necessary to get technical guidance in writing.

The characteristics and patterns of writing development are the points for implementing development activities. Development activities are focused on creating a good writing climate. The climate is raised on a written web by presenting a very simple thing, namely writing a writing idea or idea. However, the institutional characteristics become a separate obstacle in uniting common interests.

The implementation of the web site has changed in terms of layout. The web site developer is part of the Education Technology Department of the State University of Malang in coordination with partner institutions. The first concept is guidance for partner institutions. However, in the trial activities, both the Perhutani SDM and the STT Dharma Iswara Madiun Pusdikbang wanted equality as a joint developer, so it was hoped that this web site would be widely used later. So that the initial interface design implementation underwent a design change. Changes seen in the logo that appears are the logos of 3 collaborating institutions as partners.

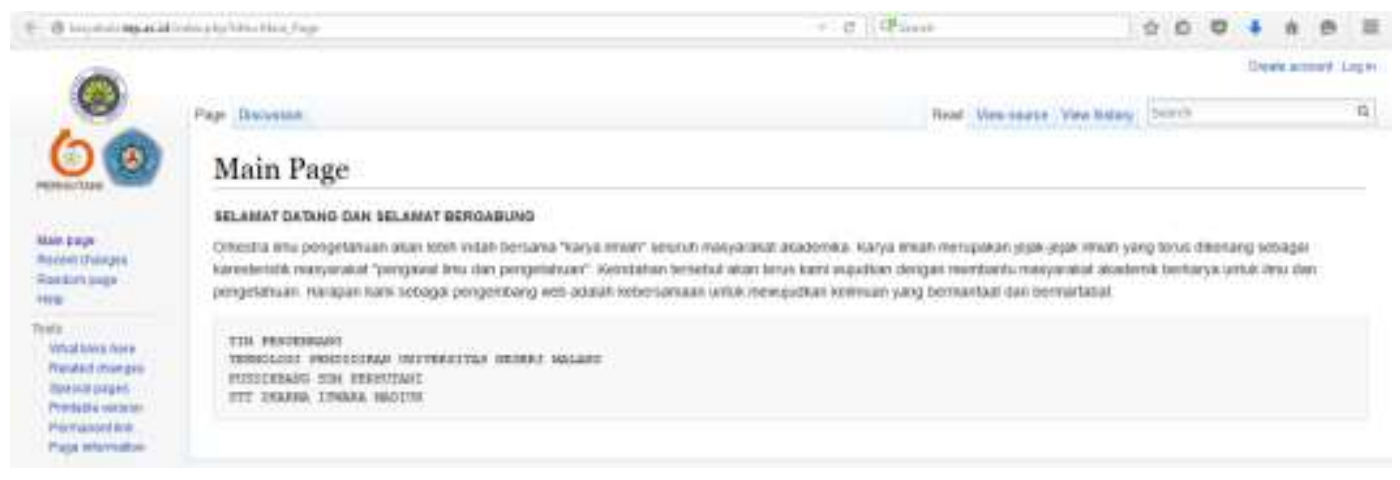

Figure 1 Display of the main web site

Adjustment in technical implementation is the administrative right of managing the web site. Educational technology department as a developer becomes the main level administrator. Partner institutions were initially only used in the development of joint meetings changed with granting rights as administrators. Technically, this affects the order of online editing. So that adjustment were made to the on-line editing Operational Guidelines. This adjustment relates to login procedures that are no longer differentiated in different interfaces but have similarities in 1 login interface with the same address, namely http://karyatulis.tep.ac.id/index.php?title=Special:UserLogin\&returnto=Main+ Page 


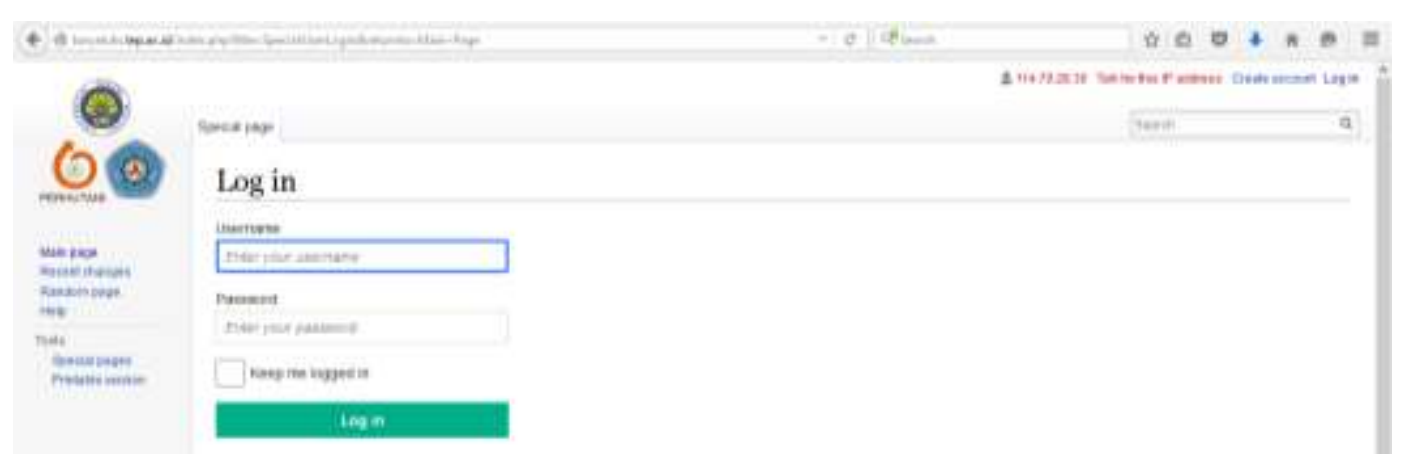

Figure 2. Display Login

The technical change in the primary institution and partner is the ability to edit jointly. Equality became the central icon in the development of the developed web. The use of a web site no longer has the right to dominate, but becomes a complete collaboration.

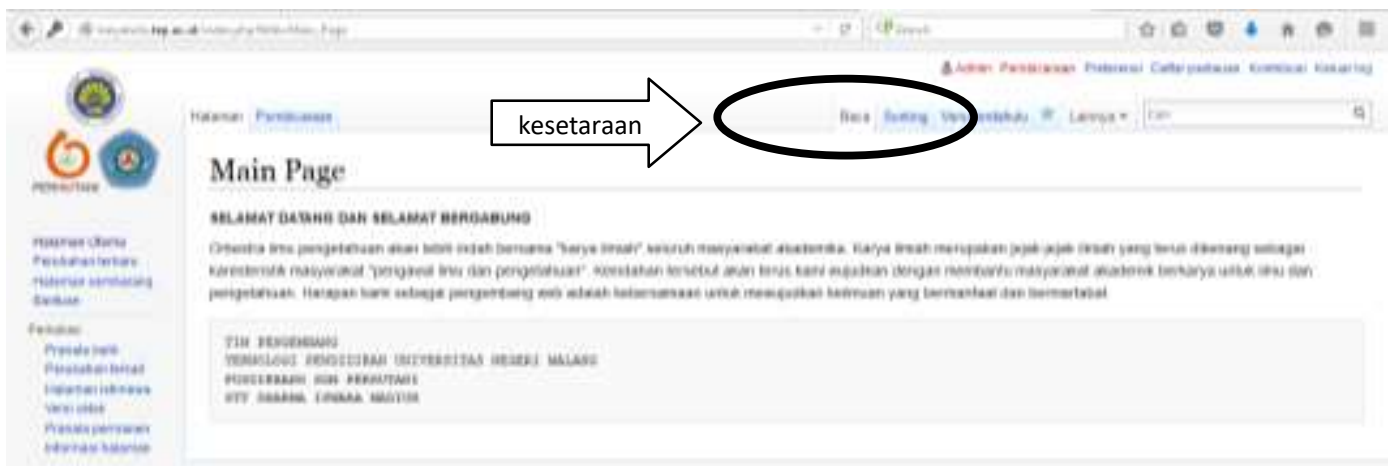

Figure 3. Equality of Ability

\section{Results of Joint Editing Implementation at TEP UM}

Implementation of the collaboration of the editorial work of scientific produces an increase in the quantity of publications journals and proceedings are significant both nationally and internationally. The ability of the development of writing paper writes scholarly among individuals each institution does have differences. But the most important thing is the similarity in spiritual development. Desire development work of writing is a desire that has long they initiated. The spirit of the lecturers of the Department of Technology Education Universitas Negeri Malang is incorporate the results written into the activities of publications nationally and internationally. As a result, the years 2016, 2017 and 2018 are as follows : 


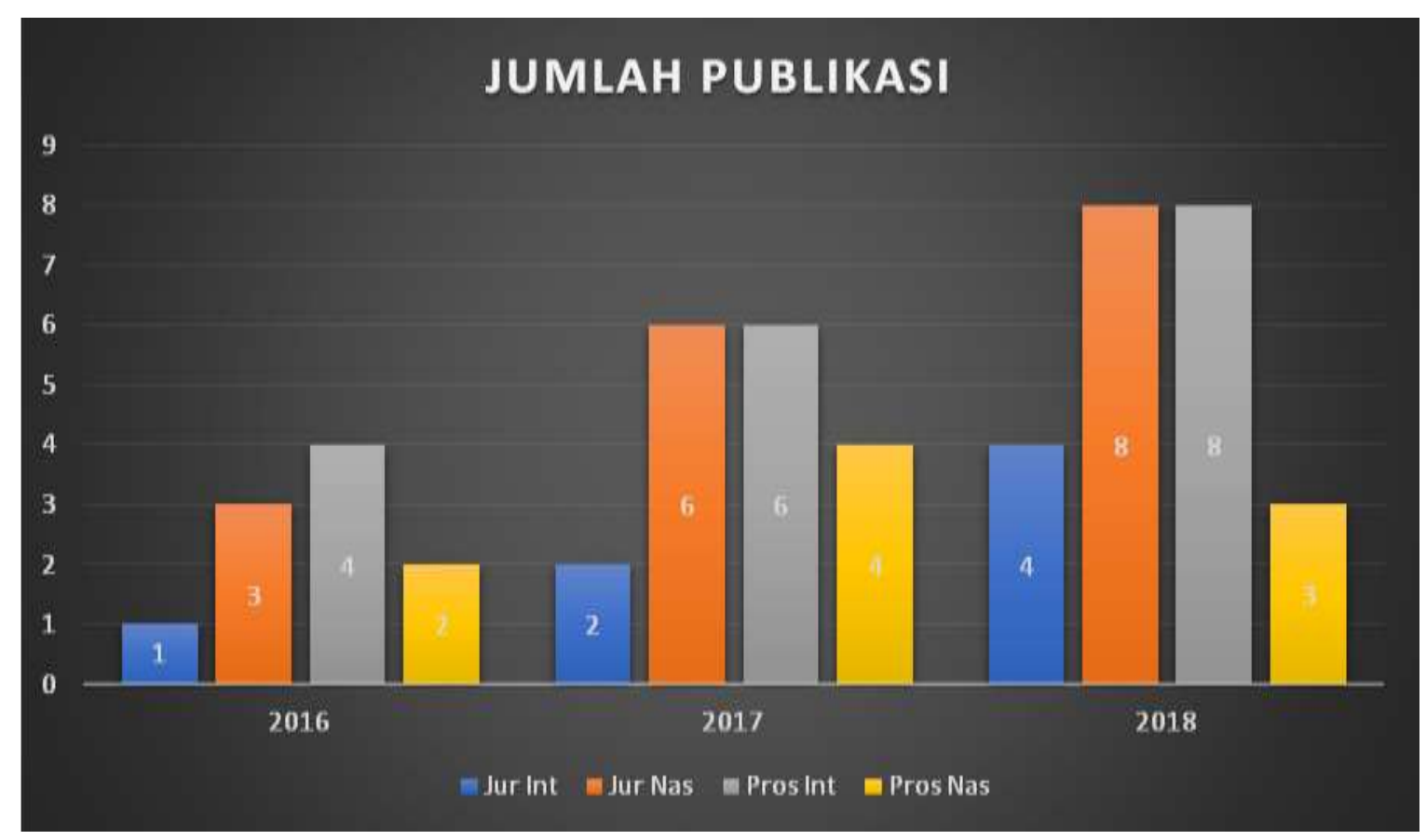

Graph 1. Data publication of scholarly years 2016, 2017 and 2018

In the period of three years, namely the year 2016 up to 2018 occurred an increase in the publication of scientific by lecturers TEP UM. In the international journal level ( Jur Int ) is a reputable journal and uses the official UN Language. For Journal national is a journal that indexed both Sprott, scholar, DOAJ or the other. For the types of international proceedings, publications are the types of proceedings that are published in international conferences and indexed by Thompson routers, Google Scholar, and Scopus. And for proceedings nationwide is the proceedings of the air -ISBN. If seen from the data presented in the above occur to increase the numbers scientific publications for TEP UM lecturers from year to year.

\section{Conclusion}

Applications editing work daily on-line has been able to build collaborative writing scientific are specific to a lecturer in the environment the University of Negeri Malang. As well as facilities that enable lecturers at the University of Negeri Malang to create, publish and share content digitally in the community socially just and cities which might already exist. In addition to a case of the application editing Arya scientific basis online this as a media collaboration online can be used as a media collaborative writing science that specific to the institution organizer of education and the learning of others.

Implementation of the application of this gives the impact that positively on the work of writing scientific users. Scientific writing as a result of media collaboration online writing for community members will have an effect on the process of construction of knowledge for future research needs and service of lecturers at the State University of Malang. In the development of online scientific writing collaboration vehicles, it will be able to manage the knowledge of Malang State University lecturers for identification and mapping of intellectual assets in the State University of Malang. Until the collaboration community of the State University of Malang lecturers will produce 1) new knowledge for competitive advantage in the learning environment, 2) make a large amount of information accessible, 2) share good practices, and 3) be able to utilize scientific writing collaboration technology online 


\section{References}

Adi, E.P., (2018). Desain Penyuntingan Online Secara Kolaborasi untuk Peningkatan Hasil Penulisan Karya Ilmiah Dosen. Edcomtech J. Kaji. Teknol. Pendidik. 3.

Adi, E.P., Praherdhiono, H., n.d. Aplikasi Kolaborasi Pengelolaan dan Penyuntingan Online Untuk Pengajar Pada Lembaga yang Memiliki Beda Karakteristik.

Boscolo, P., Ascorti, K., (2004). Effects of collaborative revision on children's ability to write of understandable narrative texts, in: Revision Cognitive and Instructional Processes. Springer, pp. 157-170.

Husna, A., Sihkabuden, S., Adi, E.P., (2017). APLIKASI KOLABORASI PENULISAN DAN PENYUNTINGAN BERBASIS WEB UNTUK PENINGKATAN MUTU KARYA ILMIAH MAHASISWA. Edcomtech J. Kaji. Teknol. Pendidik. 1, 59-68.

Kemmis, S., McTaggart, R., Nixon, R., (2015). Critical theory and critical participatory action research. Sage Los Angeles, CA.

McTaggart, R., Nixon, R., (2018). Evolution the Action Research Planners: Towards Critical Participatory Action Research, in: Education in an Era of Schooling. Springer, pp. 61-78.

Sutherland, J.A., Topping, K.J., (1999). Collaborative Creative Writing in Eight-Year-Olds: Comparing Cross-Ability Fixed Role and Same-Ability Reciprocal Role Pairing. J. Res. Read. 22, 154-179.

$\mathrm{Tu}, \mathrm{C} .-\mathrm{H} .$, (2002). The impacts of text-based CMC on online social presence. J. Interact. Online Learn. $1,1-24$.

$\mathrm{Tu}, \mathrm{C} . \mathrm{-H} .,(2002)$. The measurement of social presence in an online learning environment. Int. J. ELearn. 1, 34-45.

Tu, C.-H., Corry, M., (2002). eLearning communities. Q. Rev. Distance Educ. 3, 207-18.

Windana, F., Soepriyanto, Y., Praherdhiono, H., (2015). Pengembangan Perangkat Lunak Untuk Model Pengelolaan Kuliah Bersama pada Karakteristik Lembaga Penyelenggara Berbeda. J. STT STIKMA Int. 6, 1-8. 